\title{
Kereskedelmi forgalomban használt D-dimer-tesztek vágóértékének harmonizálása
}

\author{
Török-Nagy Beáta ${ }^{1}$. Vajda Zoltán dr. ${ }^{1,2}$. Vásárhelyi Barna dr. ${ }^{1}$ \\ ${ }^{1}$ Semmelweis Egyetem, Általános Orvostudományi Kar, Laboratóriumi Medicina Intézet, Budapest \\ ${ }^{2}$ Diagon Kft., Budapest
}

\begin{abstract}
Bevezetés: A D-dimer-teszt legfóbb indikációs területe a vénás thromboemboliás betegségek kizárása. A kereskedelemben elérhető különböző D-dimer-tesztek tulajdonságai viszont jelentősen különbözhetnek egymástól, és a velük kapott eredmények is nehezen hasonlíthatók össze.

Célkitüzés: Célunk az volt, hogy összehasonlítsunk három, kereskedelmi forgalomban lévő D-dimer-tesztet, vizsgáljuk az ugyanazon mintán kapott eredmények korrelációját, illetve a vágóértékek optimalizálásával összehangoljuk a tesztek szenzitivitását és specificitását.

Módszer: A Semmelweis Egyetemen 158, vénás thromboembolia gyanújával vizsgált beteg plazmamintájában határoztuk meg a D-dimer-szintet három különböző reagenssel. Az egyik tesztet (INNOVANCE D-Dimer) referensnek választottuk, és a másik két teszt (STA-Liatest D-Di; Dia-D-DIMER) esetében vizsgáltuk a teszt eredménye alapján pozitív/negatív betegeket, a vágóérték $0,2-1 \mu \mathrm{g} / \mathrm{ml}$ (fibrinogénekvivalens egység - FEU) közötti változtatása mellett. Khi-négyzet-próbával, illetve a diagnosztikai tesztet jellemző paraméterek számolásával megbecsültüik az optimális vágóértéket e tesztek esetében. A D-dimer-szintek korrelációját regressziós analízissel vizsgáltuk.

Eredmények: A khi-négyzet-statisztika alapján a STA-Liatest D-Di teszt 0,3 és $1 \mu \mathrm{g} / \mathrm{ml}$ (FEU) között változtatott vágóértékei mellett nincs szignifikáns különbség az INNOVANCE D-Dimer-hez képest. A Dia-D-DIMER esetében, 0,2-0,3 $\mu \mathrm{g} / \mathrm{ml}$ (FEU) vágóértékeknél szignifikáns a különbség, $0,4 \mu \mathrm{g} / \mathrm{ml}$ (FEU)-nál határeset, és $0,5-1 \mu \mathrm{g} / \mathrm{ml}$ (FEU) értékeknél nincs egyértelmú különbség a tesztekkel kapott eredmények között. A STA-Liatest D-Di szenzitivitásának értéke 82,7 és 100\% között mozgott 0,2-1 $\mu \mathrm{g} / \mathrm{ml}$ (FEU) közötti vágóértékek esetében, míg a Dia-D-DIMER-nél 92,3 és 100\% közöttiek az értékek. A specificitásértékek 50-96,3\%, illetve 35,2-87\% között mozogtak. Az optimális vágóérték becslésekor a STA-Liatest D-Di tesztnél a 0,5-0,6, míg a Dia-D-DIMER tesztnél a $0,7 \mu \mathrm{gg} / \mathrm{ml}$ (FEU) vágóértéket állapítottuk meg.

Következtetés: Minden diagnosztikus laboratóriumnak meg kell határoznia, hogy a vizsgált populációban az általa használt D-dimer-tesztnél mekkora az optimális vágóérték.
\end{abstract}

Orv Hetil. 2019; 160(15): 585-592.

Kulcsszavak: D-dimer, vágóérték, harmonizáció

\section{Harmonization of cut-off values of commercially available D-dimer tests}

Introduction: The objective of the $\mathrm{D}$-dimer tests is to exclude venous thromboembolic disorders. The characteristics of various D-dimer tests differ significantly and consequently, their results are difficult to compare.

Aim: Our goal was to compare three D-dimer tests, analyse their correlation and harmonise their sensitivity and specificity through the optimisation of cut-off values.

Method: At Semmelweis University, the D-dimer level was determined with three different reagents in 158 plasma samples, suspected with venous thromboembolism. INNOVANCE D-Dimer was selected as the referent, and in the case of the two other tests (STA-Liatest D-Di; Dia-D-Dimer), the cut-off values were changed between $0.2-1 \mu \mathrm{g} /$ $\mathrm{ml}$ (fibrinogen-equivalent unit - FEU). The optimal cut-off values were estimated by diagnostic parameters and chisquare test. The correlation of the different tests was calculated by regression analysis.

Results: Based on the chi-square statistics, there is no significant difference between STA-Liatest D-Di and INNOVANCE D-Dimer tests using the cut-off values $0.3-1 \mu \mathrm{g} / \mathrm{ml}$ (FEU) (STA-Liatest D-Di). In the case of Dia-D-DIMER, there is a significant difference using $0.2-0.3 \mu \mathrm{g} / \mathrm{ml}$ (FEU) cut-off values, $0.4 \mu \mathrm{g} / \mathrm{ml}$ (FEU) is a border-line value and using $0.5-1 \mu \mathrm{g} / \mathrm{ml}(\mathrm{FEU})$ cut-off values, there is no significant difference. The sensitivity of STA-Liatest 
D-Di changed between $82.7-100 \%$ using $0.2-1 \mu \mathrm{g} / \mathrm{ml}$ (FEU) cut-off values, while the sensitivity of Dia-D-DIMER was $92.3-100 \%$. Their specificities ranged between $50-96.3 \%$ and $35.2-87 \%$. The optimal cut-off values were estimated as $0.5-0.6 \mu \mathrm{g} / \mathrm{ml}$ (FEU) for the STA-Liatest D-Di test and $0.7 \mu \mathrm{g} / \mathrm{ml}$ (FEU) for the Dia-D-DIMER test. Conclusion: Each diagnostic laboratory should determine the optimal cut-off value of the D-dimer test in use, considering the examined population of the area.

Keywords: D-dimer, cut-off value, harmonization

Török-Nagy B, Vajda Z, Vásárhelyi B. [Harmonization of cut-off values of commercially available D-dimer tests]. Orv Hetil. 2019; 160(15): 585-592.

(Beérkezett: 2018. november 29.; elfogadva: 2018. december 23.)

\begin{abstract}
Rövidítések
$\mathrm{AUC}=($ area under the curve $)$ görbe alatti terület $; \mathrm{CE}=(\mathrm{Con}-$ formité Européenne) európai megfelelőség; DIC = (disseminated intravascular coagulation) disszeminált intravascularis koaguláció; DVT = (deep venous thrombosis) mélyvénás thrombosis; ELISA = (enzyme-linked immunosorbent assay) enzimhez kapcsolt immunszorbensvizsgálat; FEU $=($ fibrinogen-equivalent unit) fibrinogénekvivalens egység; IVD $=$ in vitro diagosztikai; $\mathrm{PE}=$ pulmonalis embolia; $\mathrm{PPV}=($ positive predictive value) pozitív prediktív érték; $\mathrm{ROC}=($ receiver operating characteristic) vevő múködési karakterisztika; VTE = (venous thromboembolism) vénás thromboembolia
\end{abstract}

A D-dimer a szekunder fibrinolízis során jelenik meg a vérben, a keresztkötött fibrinháló proteolízisének eredménye. A fibrinből származó D-dimer két D-doménből áll, melyeket kovalens kötés köt össze az Y-lánc C-terminálisánál [1]. A keresztkötött fibrin enzimatikus hasítása során egyéb fibrindegradációs termékek, nagy molekulatömegú X-oligomerek is keletkeznek, melyek ugyancsak tartalmazzák a dimerizált D-doméneket: DY $(247 \mathrm{kDa})$, YY (285 kDa), DXD (461 kDa), YXD (500 kDa), XY (391 kDa) [2].

Napjainkban a klinikai gyakorlatban jelentős szerepe van a $\mathrm{D}$-dimer-szint mérésének a mélyvénás thrombosis (DVT) és a pulmonalis embolia (PE) kizárásában. A vágóérték alatti értékek esetén ugyanis a kis kockázatú betegeknél nagy biztonsággal zárható ki mind a DVT, mind a PE [3-5].

A D-dimer-szint mérésére a kereskedelemben számos teszt érhető el, melyek különböző elveken alapulnak (ELISA, latex immunturbidimetriás teszt stb.), eltéró epitópokra optimalizáltak. Lehetnek kvalitatív, kvantitatív, szemikvantitatív tesztek. Általános problémát jelent, hogy az egyes D-dimer-tesztek nehezen harmonizálhatók, mert tulajdonságaik jelentősen különbözhetnek egymástól. Ezért a velük kapott eredmények is nehezen hasonlíthatók össze, s mindezek zavarják a klinikai döntéshozatalt.

További problémát vet fel az, hogy a gyártók általában egységesen a $0,5 \mu \mathrm{g} / \mathrm{ml}$ (FEU) vagy a $0,25 \mu \mathrm{g} / \mathrm{ml}$ (DD) vágóértékeket („cut-off value”) rendelik hozzá a D-dimer-tesztekhez. Ez az az érték, amelyet megszoktak a felhasználók. Ez viszont az adott teszttól, a vizsgált populációtól, illetve egyéb tényezőktől függően is változhat. Jelen munkánk során Magyarországon forgalmazott három D-dimer-teszt esetében végeztük el a tesztek öszszehasonlítását és a vágóértékek harmonizációját.

\section{Módszer}

A Semmelweis Egyetemen 158, vénás thromboembolia (VTE) gyanúja miatt vizsgált betegtől kaptunk plazmamintát, amelyekből a klinikus DVT vagy PE kizárása érdekében D-dimer-szint-meghatározást kért.

\section{A D-dimer-szint meghatározása}

A mintákat három különböző immunturbidimetriás Ddimer-teszttel (INNOVANCE D-Dimer [Siemens, Marburg, Németország], STA-Liatest D-Di [Diagnostica Stago, Asnières-sur-Seine, Franciaország], Dia-D-DIMER [DIAGON Kft., Budapest, Magyarország]) mértük. A mérések elvégzéséhez az adott tesztekhez ajánlott koagulométereket alkalmaztuk: BCS (Siemens), STA Compact (Diagnostica Stago), COAG XL (Diagon $\mathrm{Kft}$.). A maradék mintát $-80^{\circ} \mathrm{C}$-on két aliquotban tároltuk a másik két teszttel való lemérésig. A használt vérminták vizsgálata a maradék minták felhasználására vonatkozó törvény hatálya alá esett (lásd az Egészségügyről szóló 1997. évi CLIV. törvény 210/A \$-át).

A méréseket a Semmelweis Egyetem Laboratóriumi Medicina Intézetében végeztük.

A klinikai döntéshozatalra használt INNOVANCE DDimer teszt esetében az értékeléskor a gyártó által megadott $0,5 \mu \mathrm{g} / \mathrm{ml}$ (FEU) vágóértéket alkalmaztuk, míg a másik két tesztnél a vágóértéket 0,2 és $1 \mu \mathrm{g} / \mathrm{ml}$ (FEU) között változtattuk, és így törekedtünk azonos szenzitivitás- és specificitásértékek elérésére. A gyártók által megadott tesztjellemzőket az 1. táblázat foglalja össze. 
1. táblázat |A vizsgálatban használt D-dimer-tesztek analitikai paraméterei

\begin{tabular}{llll}
\hline & Dia-D-DIMER & STA-Liatest D-Di & INNOVANCE D-Dimer \\
\hline A módszer elve & Immunturbidimetriás teszt & Immunturbidimetriás teszt & Immunturbidimetriás teszt \\
\hline Mérési tartomány & $0,22-8,00 \mu \mathrm{g} / \mathrm{ml}(\mathrm{FEU})$ & $\begin{array}{l}0,27-4,00 \mu \mathrm{g} / \mathrm{ml}(\mathrm{FEU}) \\
{[20 \mu \mathrm{g} / \mathrm{ml}(\mathrm{FEU}) \mathrm{mintahígítással}]}\end{array}$ & $0,12-4,46 \mu \mathrm{ml}(\mathrm{FEU})$ \\
\hline $\begin{array}{l}\text { A tesztben alkalmazott } \\
\text { ellenanyag }\end{array}$ & $\begin{array}{l}\text { Antihumán D-dimer monoklonális } \\
\text { ellenanyag }\end{array}$ & $\begin{array}{l}\text { Antihumán D-dimer monoklonális } \\
\text { ellenanyag }(8 \mathrm{D} 2 \text { és 2.1.16) }\end{array}$ & Monoklonális ellenanyag $(8 \mathrm{D} 3)$ \\
& & & $<0,5 \mu \mathrm{mg} / \mathrm{ml}(\mathrm{FEU})$ \\
\hline $\begin{array}{l}\text { A gyártó által kiadott } \\
\text { normálérték }\end{array}$ & $<0,5 \mu \mathrm{g} / \mathrm{ml}(\mathrm{FEU})$ & $<0,5 \mu \mathrm{ml}(\mathrm{FEU})$ & $<$ \\
\hline
\end{tabular}

FEU = fibrinogénekvivalens egység

\section{Statisztikai elemzés}

Az értékelés során a mintákat a vágóértékek alapján minden teszt esetében pozitív és negatív D-dimerú csoportokba soroltuk. A létrehozott csoportok közötti összehasonlítást a khi-négyzet statisztikai próbával végeztük. Vizsgálatunkban szignifikáns eltérésnek a $\mathrm{p}<0,05$ értéket tekintettük. A STA-Liatest D-Di és a Dia-D-DIMER teszt esetében a különböző vágóértékeknél számolt diagnosztikai specificitás- és szenzitivitásértékeket ROCgörbével ábrázoltuk. A ROC-görbéket az online VassarStats programmal (http://vassarstats.net/) készítettük.

A tesztek értékeléséhez szükséges, „valós pozitív”, illetve „valós negatív” értékek megadásához a jelen tanulmányban az INNOVANCE D-Dimer teszt eredményeit vettük alapul. Az optimális küszöbértékek meghatározásához az Accuracy („osztályozási pontosság”) Youdenindex-mutatókat számoltuk.

A tesztek numerikus eredményeinek összehasonlítását Bland-Altman-korrelációval végeztük.

\section{Eredmények}

A három D-dimer-teszttel történő méréssorozat után a mintákat pozitív, illetve negatív D-dimerű csoportokba soroltuk, az egyes tesztek során használt vágóértékek alapján. A STA-Liatest D-Di és a Dia-D-DIMER tesztnél változtattuk a vágóértéket, így $0,2-1 \mu \mathrm{g} / \mathrm{ml}$ FEU vágóérték-tartományban is létrehoztunk pozitív és negatív eredményű csoportokat (2. táblázat).

Az INNOVANCE D-Dimer teszttel mérve 104 minta a pozitív, míg 54 a negatív csoportba tartozik. A STALiatest D-Di esetében a vágóérték változtatásával 88 131 minta a pozitív és 27-70 a negatív csoportba kerül. A Dia-D-DIMER teszttel végezve a mérést, 103-139 minta a pozitív, míg 19-55 a negatív csoportba tartozik.

A 2. táblázat adataiból khi-négyzet statisztikai elemzést végeztünk, melyet a 3. táblázat mutat be. $\alpha=0,05$ szignifikanciaszintet választva, a STA-Liatest $\mathrm{D}$-Di teszt 0,3 és $1 \mu \mathrm{g} / \mathrm{ml}$ (FEU) között változtatott vágóértékei mellett nincs szignifikáns különbség az INNOVANCE
D-Dimer teszthez képest $(p>0,05)$. A Dia-D-DIMER teszt esetében minél magasabb vágóértéket választunk, annál kisebb a különbség a pozitív-negatív betegek megoszlásában a referenciateszthez viszonyítva. $0,2-0,3 \mu \mathrm{g} /$ $\mathrm{ml}$ (FEU) vágóértékeknél szignifikáns a különbség a két teszt között $(\mathrm{p}<0,05), 0,4 \mu \mathrm{g} / \mathrm{ml}$ FEU-nál határeset $(\mathrm{p}=0,048)$, és $0,5-1 \mu \mathrm{g} / \mathrm{ml} \mathrm{FEU}$ értékeknél egyértelmúen nincs különbség a tesztek között.

A tesztek numerikus eredményei közötti kapcsolatot Bland-Altman-korrelációval vizsgáltuk [6] (1. és 2. ábra). Az átlagtól való maximumeltérés a STA-Liatest

\section{2. táblázat $\mid$ Pozitív $(\mathrm{P})$, illetve negatív $(\mathrm{N})$ csoportba sorolt betegek a három teszt esetében, a STA-Liatest D-Di és a Dia-D-DIMER tesztnél $0,2-1 \mathrm{\mu g} / \mathrm{ml}$ (FEU) között változtatott vágóértékekkel. A cel- lába írt első számadat az egyének számát mutatja az összes, 158 beteg közül, míg a zárójeles érték ennek százalékos kifejezése}

\begin{tabular}{|c|c|c|c|c|}
\hline Vágóérték & $\begin{array}{l}\text { Pozitív/ } \\
\text { Negatív }\end{array}$ & $\begin{array}{l}\text { INNOVANCE } \\
\text { D-Dimer }\end{array}$ & $\begin{array}{l}\text { STA-Liatest } \\
\text { D-Di }\end{array}$ & $\begin{array}{l}\text { Dia-D- } \\
\text { DIMER }\end{array}$ \\
\hline \multirow[t]{2}{*}{0,2} & $\mathrm{P}$ & & $131(82,9)$ & $139(88,0)$ \\
\hline & $\mathrm{N}$ & & $27(17,1)$ & $19(12,0)$ \\
\hline \multirow[t]{2}{*}{0,3} & $\mathrm{P}$ & & $111(70,3)$ & $127(80,4)$ \\
\hline & $\mathrm{N}$ & & $47(29,7)$ & $31(19,6)$ \\
\hline \multirow[t]{2}{*}{0,4} & $\mathrm{P}$ & & $104(65,8)$ & $120(76,0)$ \\
\hline & $\mathrm{N}$ & & $54(34,2)$ & $38(24,0)$ \\
\hline \multirow[t]{2}{*}{0,5} & $\mathrm{P}$ & $104(65,8)$ & $102(64,6)$ & $118(74,7)$ \\
\hline & $\mathrm{N}$ & $54(34,2)$ & $56(35,4)$ & $40(25,3)$ \\
\hline \multirow[t]{2}{*}{0,6} & $\mathrm{P}$ & & $102(64,6)$ & $112(70,9)$ \\
\hline & $\mathrm{N}$ & & $56(35,4)$ & $46(29,1)$ \\
\hline \multirow[t]{2}{*}{0,7} & $\mathrm{P}$ & & $100(63,3)$ & $107(67,7)$ \\
\hline & $\mathrm{N}$ & & $58(36,7)$ & $51(32,3)$ \\
\hline \multirow[t]{2}{*}{0,8} & $\mathrm{P}$ & & $97(61,4)$ & $105(66,5)$ \\
\hline & $\mathrm{N}$ & & $61(38,6)$ & $53(33,5)$ \\
\hline \multirow[t]{2}{*}{0,9} & $\mathrm{P}$ & & $92(58,2)$ & $103(65,2)$ \\
\hline & $\mathrm{N}$ & & $66(41,8)$ & $55(34,8)$ \\
\hline \multirow[t]{2}{*}{1} & $\mathrm{P}$ & & $88(55,7)$ & $103(65,2)$ \\
\hline & $\mathrm{N}$ & & $70(44,3)$ & $55(34,8)$ \\
\hline
\end{tabular}

FEU = fibrinogénekvivalens egység 
3. táblázat |Khi-négyzet-próba a három teszt pozitív, illetve negatív eredményei alapján, $\alpha=0,05$-ös szignifikanciaszint mellett

\begin{tabular}{lcccccccccccc}
\hline & \multicolumn{1}{c}{ STNOVANCE D-Dimer } & \multicolumn{1}{c}{ STiatest D-Di } \\
\hline Vágóérték $[\mu \mathrm{g} / \mathrm{ml}(\mathrm{FEU})]$ & 0,5 & 0,2 & 0,3 & 0,4 & 0,5 & 0,6 & 0,7 & 0,8 & 0,9 & 1 \\
\hline Pozitív & 104 & 131 & 111 & 104 & 102 & 102 & 100 & 97 & 92 & 88 \\
\hline Negatív & 54 & 27 & 47 & 54 & 56 & 56 & 58 & 61 & 66 & 70 \\
\hline p-érték & & 0,001 & 0,398 & 1,000 & 0,813 & 0,813 & 0,638 & 0,413 & 0,164 & 0,065 \\
\hline
\end{tabular}

\begin{tabular}{lccrrrrrrrrr}
\hline & \multicolumn{1}{c}{ INNOVANCE D-Dimer } & \multicolumn{1}{c}{ Dia-D-DIMER } \\
\hline Vágóérték $[\mu \mathrm{g} / \mathrm{ml}(\mathrm{FEU})]$ & 0,5 & 0,2 & 0,3 & 0,4 & 0,5 & 0,6 & 0,7 & 0,8 & 0,9 & 1 \\
\hline Pozitív & 104 & 139 & 127 & 120 & 118 & 112 & 107 & 105 & 103 & 103 \\
\hline Negatív & 54 & 19 & 31 & 38 & 40 & 46 & 51 & 53 & 55 & 55 \\
\hline p-érték & & 0,000 & 0,003 & 0,048 & 0,0850 & 0,333 & 0,720 & 0,905 & 0,906 & 0,906 \\
\hline
\end{tabular}

FEU = fibrinogénekvivalens egység

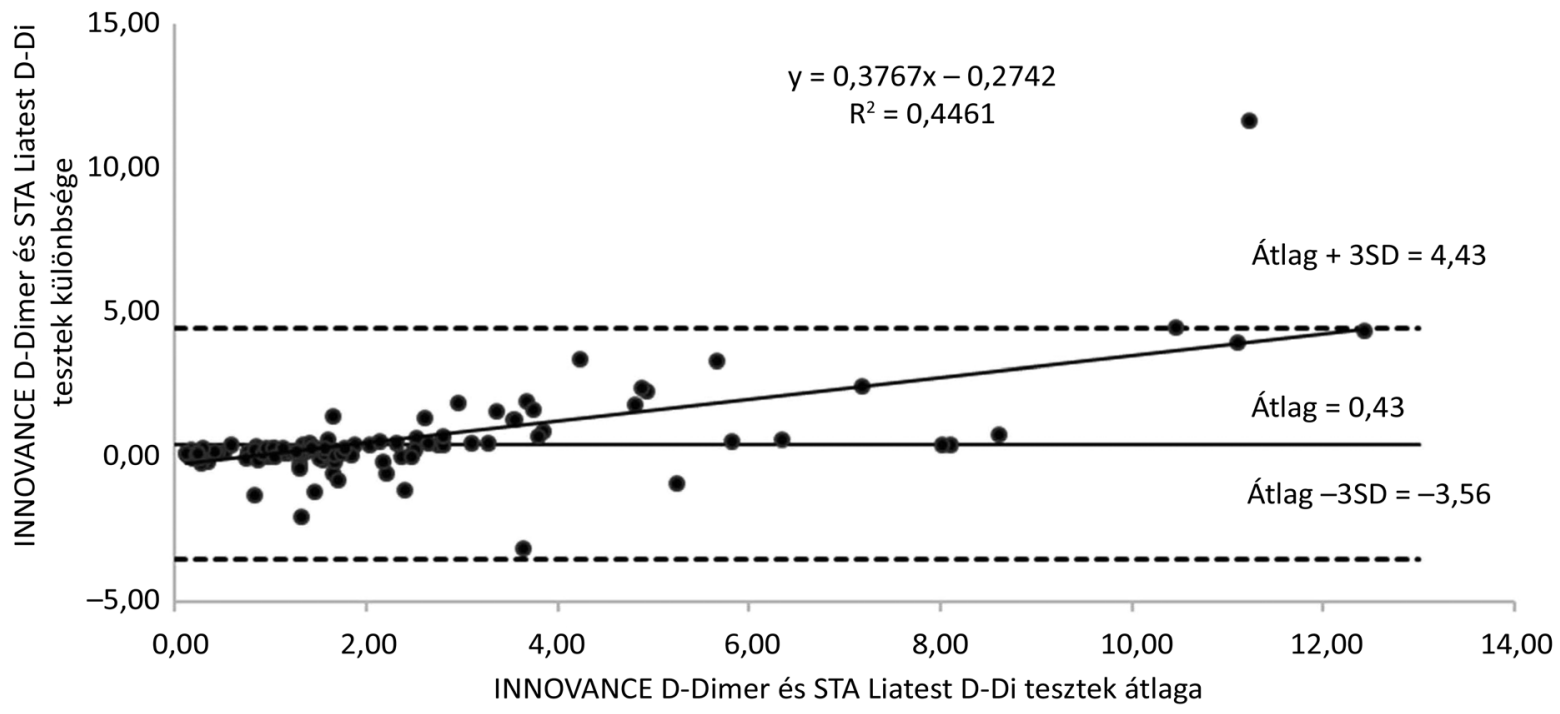

1. ábra $\mid$ Bland-Altman-korreláció az INNOVANCE D-Dimer és a STA-Liatest D-Di teszt között

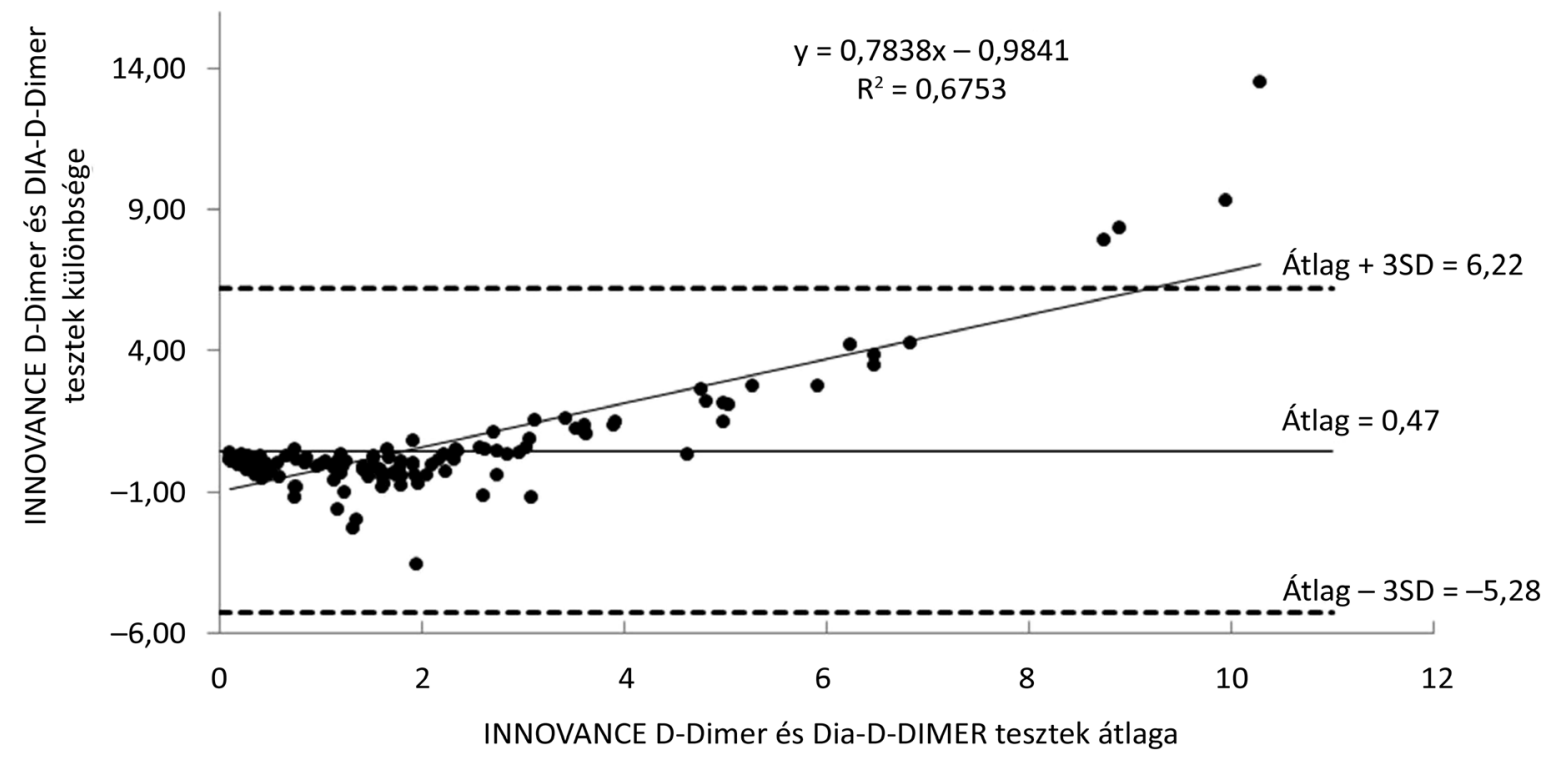

2. ábra $\quad$ Bland-Altman-korreláció az INNOVANCE D-Dimer és a Dia-D-DIMER teszt között 


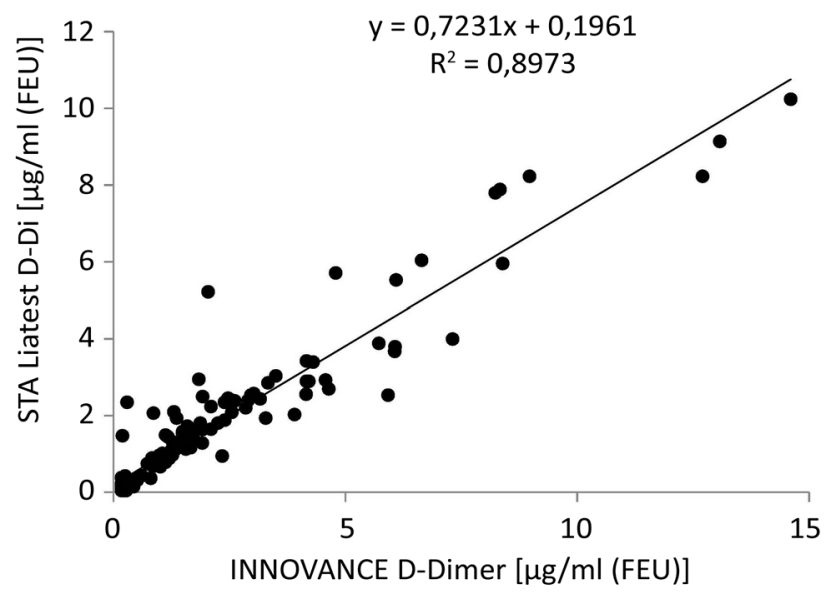

3. ábra $\mid$ Lineáris regresszió az INNOVANCE D-Dimer és a STA-Liatest D-Di teszttel mért mintákon

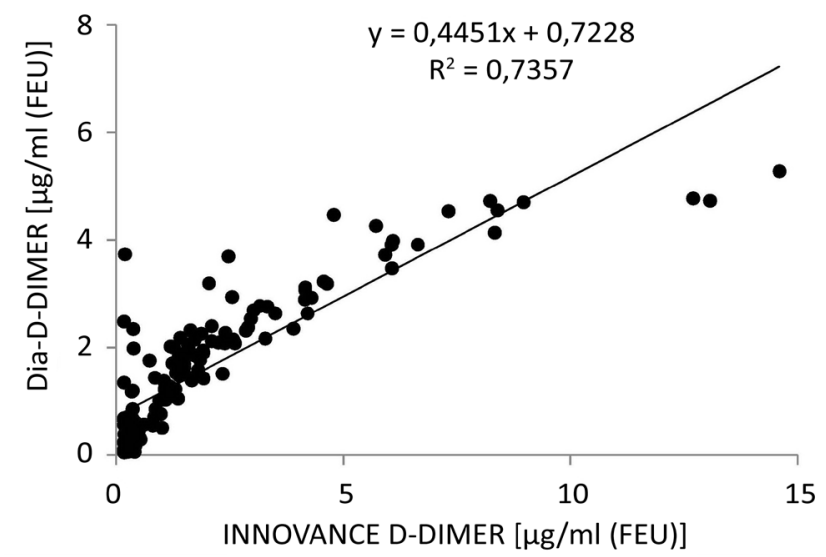

4. ábra $\mid$ Lineáris regresszió az INNOVANCE D-Dimer és a Dia-D DIMER teszttel mért mintákon

D-Di és az INNOVANCE D-Dimer esetében 11,64, míg az INNOVANCE D-Dimer és a Dia-D-DIMER teszt összevetésekor 13,5 volt. A tesztek regressziós analízisét a 3. és 4. ábra mutatja be; az $\mathrm{R}^{2}$-értékek az INNOVANCE D-Dimer és a STA-Liatest D-Di esetében $\mathrm{R}^{2}=$ 0,8973, míg az INNOVANCE D-Dimer és a Dia-D-DIMER tesztnél $\mathrm{R}^{2}=0,7357$.

Meghatároztuk a tesztek specificitás- és szenzitivitásértékeit a különböző vágóértékeknél. Referenciatesztként az INNOVANCE D-Dimer tesztet használtuk (4. táblázat).

A STA-Liatest D-Di szenzitivitásértékei (valós pozitív ráta) 0,2 és $1 \mu \mathrm{g} / \mathrm{ml}$ (FEU) közötti vágóértékek esetében $82,7 \%$ és $100 \%$ között mozogtak, míg a Dia-D-DIMER tesztre számolva 92,3\% és 100\% közöttiek az értékek. A tesztek specificitása (valós negatív ráta) az előbbi leolvasást követve, $50 \%$ és $96,3 \%$, illetve $35,2 \%$ és $87 \%$ között változik.

A különböző vágóértékekhez rendelt specificitás- és szenzitivitásértékek meghatározásával megszerkesztettük a két teszt ROC-görbéjét a referenciateszthez viszo-

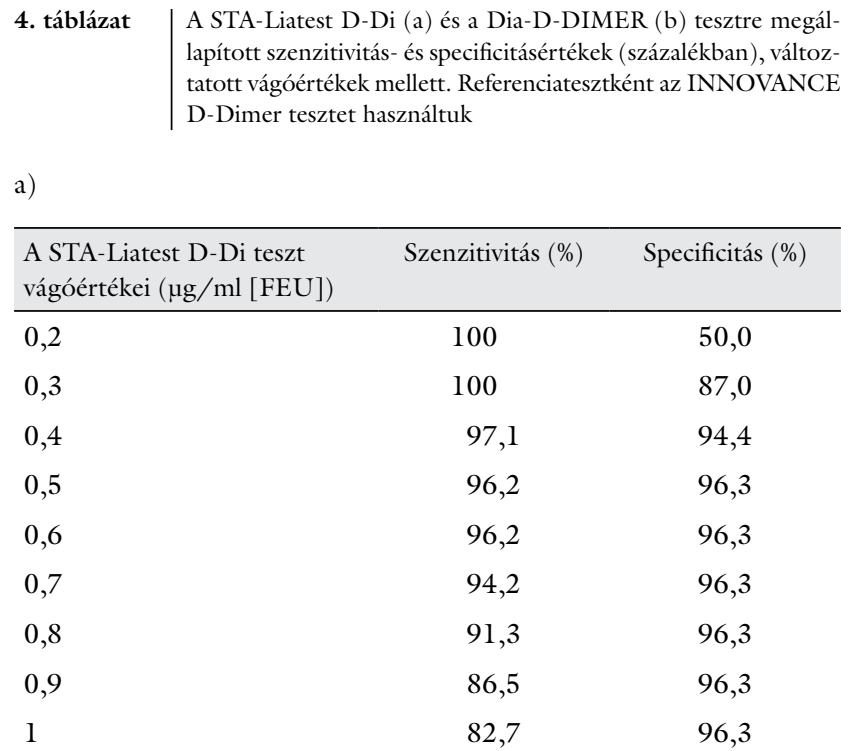

b)

\begin{tabular}{lcc}
\hline $\begin{array}{l}\text { A Dia-D-DIMER teszt } \\
\text { vágórtékei }(\mu \mathrm{g} / \mathrm{ml}[\mathrm{FEU}])\end{array}$ & Szenzitivitás $(\%)$ & Specificitás $(\%)$ \\
\hline 0,2 & 100 & 35,2 \\
0,3 & 99 & 55,6 \\
0,4 & 98,1 & 66,7 \\
0,5 & 98,1 & 70,4 \\
0,6 & 95,2 & 75,9 \\
0,7 & 95,2 & 85,2 \\
0,8 & 93,3 & 85,2 \\
0,9 & 92,3 & 87 \\
1 & 92,3 & 87 \\
\hline
\end{tabular}

FEU = fibrinogénekvivalens egység

nyítva. A görbe alatti terület (AUC) jellemzi a teszt hatékonyságát, melynek értéke a STA-Liatest D-Di tesztnél 0,9804, míg a Dia-D-DIMER tesztnél 0,9707 (5. és 6. ábra).

A tesztet jellemző kritériumokat az 5. táblázat foglalja össze. Az értékek információt adnak az optimális vágóértékról. Ehhez a legmagasabb „osztályozási pontosság” (Accuracy) 0,962, illetve 0,918, és Youden-indexet 0,925 , illetve 0,804 értéket kell figyelembe venni, melyek a STA-Liatest D-Di tesztnél a 0,5-0,6, míg a DiaD-DIMER tesztnél a $0,7 \mu \mathrm{g} / \mathrm{ml}$ (FEU) vágóértékhez tartoznak (5. táblázat).

\section{Megbeszélés}

Napjainkban a kórházi laboratóriumokban használt, CEés IVD-minősített D-dimer-tesztek teljesítménye eltérő: egyazon minta esetében az általuk mért eredmények különbözhetnek, mivel eltérnek a felhasznált ellenanyagban, specificitásukban, szenzitivitásukban, és más-más keresztreakciókat adhatnak. Nehéz ezek ismeretében a 
ROC Curve for $y=0,02 \operatorname{Ln}(x)+1$

Area under curve $=0,9804$

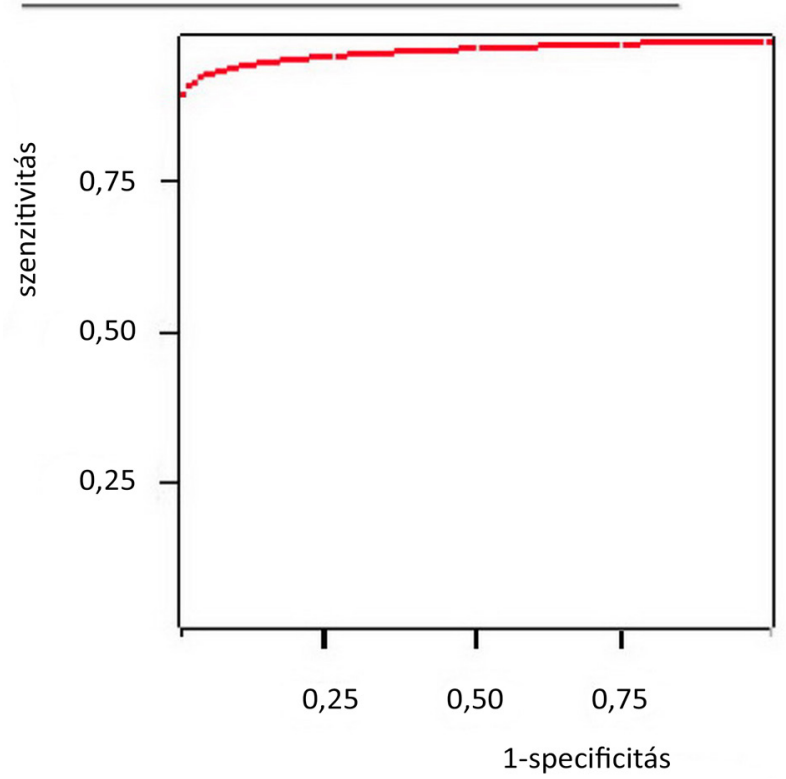

5. ábra

| A STA-Liatest D-Di teszt ROC-görbéje

ROC Curve for $y=0,03 \operatorname{Ln}(x)+1$

Area under curve $=0,9707$

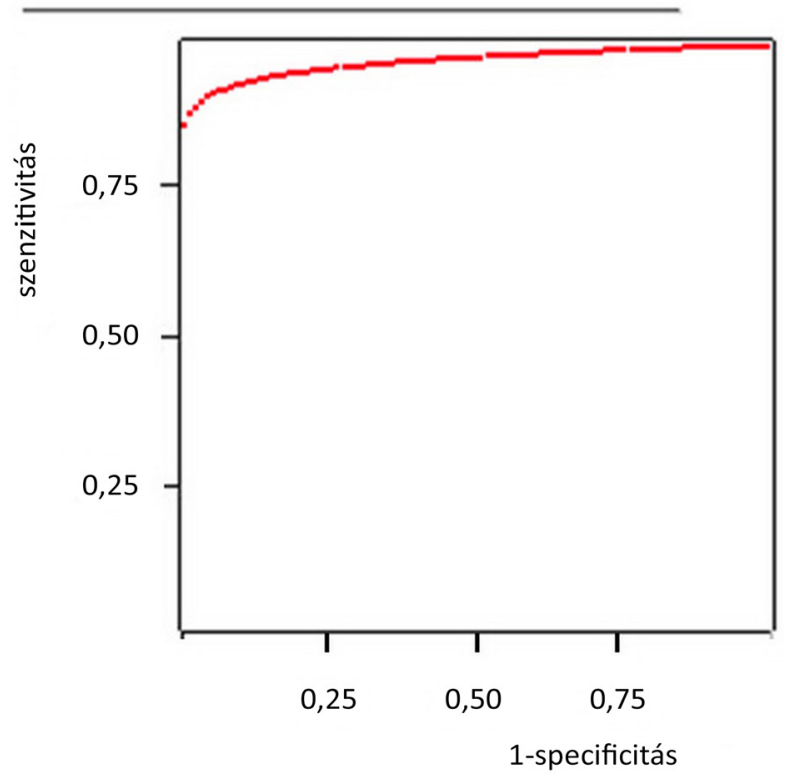

6. ábra

| A Dia-D-DIMER teszt ROC-görbéje

teszteket rangsorolni. Mindezek zavart okozhatnak a klinikusok számára az eredmények értékelésekor. A nem pontos D-dimer-eredmény a klinikai döntéshozatalt, ezen keresztül pedig a betegbiztonságot nagymértékben veszélyeztetheti.
5. táblázat |Accuracy- és Youden-index értékek

a) A STA-Liatest D-Di különböző vágóértékei esetében

\begin{tabular}{lcc}
\hline $\begin{array}{l}\text { A STA-Liatest D-Di teszt } \\
\text { vágóértékei }[\mu \mathrm{g} / \mathrm{ml}(\mathrm{FEU})]\end{array}$ & Accuracy & Youden-index \\
\hline 0,2 & 0,829 & 0,500 \\
0,3 & 0,955 & 0,870 \\
0,4 & 0,962 & 0,916 \\
0,5 & 0,962 & 0,925 \\
0,6 & 0,962 & 0,925 \\
0,7 & 0,949 & 0,905 \\
0,8 & 0,930 & 0,876 \\
0,9 & 0,899 & 0,828 \\
1 & 0,873 & 0,790 \\
\hline
\end{tabular}

b) A Dia-D-Dimer különböző vágóértékei esetében

\begin{tabular}{lcc}
\hline $\begin{array}{l}\text { A Dia-D-DIMER teszt } \\
\text { vágóértékei }(\mu \mathrm{g} / \mathrm{ml}[\mathrm{FEU}])\end{array}$ & Accuracy & Youden-index \\
\hline 0,2 & 0,779 & 0,352 \\
0,3 & 0,842 & 0,546 \\
0,4 & 0,873 & 0,647 \\
0,5 & 0,886 & 0,685 \\
0,6 & 0,886 & 0,711 \\
0,7 & 0,918 & 0,804 \\
0,8 & 0,905 & 0,785 \\
0,9 & 0,905 & 0,793 \\
1 & 0,905 & 0,793 \\
\hline
\end{tabular}

FEU = fibrinogénekvivalens egység

Adam és mtsai szerint a tesztek közötti különbségek egyik fó oka, hogy hiányzik egy általánosan elfogadott nemzetközi D-dimer-standard, melyhez a tesztek igazodhatnának, de további tényezők is befolyással bírnak. Egyrészt a különböző tesztek más-más ellenanyagot építenek be a rendszerükbe, tehát a D-dimer-specifikus ellenanyag nem ugyanazt az epitópot ismeri fel az antigén felületén, hanem különböző epitópokat; ennek következtében a különböző tesztek ellenanyagai más és más specificitással bírnak, így eltérő mértékben adnak keresztreakciókat is. Szinte minden teszt ellenanyaga keresztreagál bizonyos mértékben a keresztkötött D-dimeren kívül más fibrin- vagy fibrinogéndegradációs termékkel, melyek a plazmában változó mennyiségben vannak jelen, s ez a teszt specificitásában jelentős különbségeket idéz elő. Az is előfordul, hogy egy tesztben több különböző specificitású ellenanyagot is használnak [7].

Mindezek mellett interferenciát okozó anyagok (mint például heterofil antitestek vagy rheumatoid faktor) is okozhatnak különbségeket a tesztek között, mivel az egyes tesztek eltérő mértékben képesek a mintában lévő zavaró, interferáló anyagokat „kiszürni” $[8,9]$. 
A D-dimer-tesztek harmonizációjával, standardizációjával már több tanulmányban is foglalkoztak $[10,11]$. Mullier és mtsai öt különböző $\mathrm{D}$-dimer-tesztet hasonlítottak össze; a teszteredmények közti különbségek csökkentésére a vágóértékeket változtatták meg, figyelembe véve a betegek életkorát [12].

Hager és mtsai igazolták, hogy a D-dimer értéke az életkor előrehaladtával emelkedik [13]. Az ADJUST-PE tanulmányban időskorú betegek esetében vizsgálták a Ddimer VTE-t kizáró vágóértékét. Vizsgálatuk során az 50 év feletti betegeknél a korral arányosan növelték a vágóértéket, az életkort szorozták meg 10-zel. Arra a következtetésre jutottak, hogy az életkorral korrigált D-dimer-vágóérték - szemben a konvencionális $500 \mu \mathrm{g} / \mathrm{l}$ (FEU) értékkel - diagnosztikai értéke nagyobb; nagyobb számú (egyébként alacsony kockázatú) betegnél lehetett biztonsággal kizárni a tüdőemboliát $[14,15]$. Számos későbbi tanulmányban is előnyösnek találták a D-dimervágóérték korspecifikus változtatását [16-21].

Jelen munkának célja az volt, hogy három, forgalomban lévő D-dimer-tesztet összehasonlítson, közülük egy tesztet referenciának tekintve, és ehhez képest a többi tesztet jellemezze a következő paraméterek megadásával: ROC-görbe, szenzitivitás, specificitás [22]. Vizsgáltuk továbbá, hogy a tesztek küszöbértékét változtatva hogyan módosul a deklarált teszteredmény, s mindezek mellett a tesztek optimális vágóértékét becsültük meg.

Munkánk során önkényesen az INNOVANCE D-Dimer-t tekintettük referenciatesztnek, és másik két tesztet hasonlítottunk hozzá, melyeknél a teszt vágóértékét változtattuk, és vizsgáltuk, hogy ennek során van-e a tesztek által nyújtott információban különbség, illetve az optimális vágóértéket kerestük, melyet több szempont alapján vizsgáltunk.

A laboratóriumok általában egyöntetüen $0,5 \mu \mathrm{g} / \mathrm{ml}$ (FEU) vágóértéket használnak a VTE kizárására. Ez azonban nem helyes, a vágóérték ugyanis függ a vizsgált populációtól is.

Munkánkban 158, a Semmelweis Egyetemen kezelt beteg mintáján végeztük el az összehasonlítást, akiknek a jelentős hányadánál a referenciateszt alapján magas volt a D-dimer-szint. A 4. táblázatban feltüntetett adatok egyértelmüen jelzik, hogy a vágóérték változtatásával jelentôsen változnak a szenzitivitás- és specificitásértékek is.

Kisebb vágóértéket választva nő az érzékenység, mivel a negatív eredmények száma csökken, ellenben a hamis pozitívaké nőhet. Ezzel ellentétesen, ha a vágóértéket növeljük, nagyobb specificitást érünk el, több hamis negatív és kevesebb hamis pozitív esetet kapunk.

A vágóérték-optimalizálás során az Accuracy-értéket és a Younden-indexet is használtuk. E mutatók eredményei szerint a STA-Liatest D-Di tesztnél a 0,5-0,6 $\mu \mathrm{g} / \mathrm{ml}$ (FEU) vágóértékek, míg a Dia-D-DIMER tesztnél a 0,7 $\mu \mathrm{g} / \mathrm{ml}$ (FEU) vágóérték az, mely a legjobban harmonizál az INNOVANCE D-Dimer esetében használt 0,5 $\mu \mathrm{g} / \mathrm{ml}$ (FEU) vágóértékkel.

\section{Következtetés}

Eredményeink alátámasztják: bár általában 'univerzális' a D-dimer-vágóérték $(0,5 \mu \mathrm{g} / \mathrm{ml}$ [FEU]), minden laboratóriumnak meg kell határoznia a vizsgált populációra és klinikai használatra (például a VTE kizárására) alakított vágóértéket az általa használt $\mathrm{D}$-dimer-tesztre, az általa vizsgált populációban. Ennek különös jelentősége van akkor, amikor új tesztre térnek át.

Anyagi támogatás: A közlemény megírása, illetve a kapcsolódó kutatómunka anyagi támogatásban nem részesült.

Szerzői munkamegosztás: T.-N. B.: Az irodalomkutatás elvégzése, a mérésekben való részvétel, statisztikai elemzés végzése, a kézirat megírása. V. Z.: A kézirat szakmai véleményezése, statisztikai elemzés végzése. V. B.: A kézirat lektorálása, szakmai véleményezése. A cikk végleges változatát valamennyi szerző elolvasta és jóváhagyta.

Érdekeltségek: A szerzők egyike, dr. Vajda Zoltán a Diagon Kft. alkalmazottja.

\section{Irodalom}

[1] Dempfle C-E. Validation, calibration, and specificity of quantitative D-dimer assays. Semin Vasc Med. 2005; 5: 315-320.

[2] Francis CW, Marder VJ, Barlow GH. Plasmic degradation of crosslinked fibrin. Characterization of new macromolecular soluble complexes and a model of their structure. J Clin Invest. 1980; 66: 1033-1043.

[3] Wells PS, Anderson DR, Rodges M, et al. Derivation of a simple clinical model to categorize patients probability of pulmonary embolism: increasing the models utility with the SimpliRED Ddimer. Thromb Haemost. 2000; 83: 416-420.

[4] Wells PS. Integrated strategies for the diagnosis of venous thromboembolism. J Thromb Haemost. 2007; 5(Suppl 1): 41-50.

[5] Wicki J, Perneger TV, Junod AF, et al. Assessing clinical probability of pulmonary embolism in the emergency ward: a simple score. Arch Intern Med. 2001; 161: 92-97.

[6] Bland JM, Altman DG. Statistical methods for assessing agreement between two methods of clinical measurement. Lancet 1986; 1(8476): P307-P310.

[7] Adam SS, Key NS, Greenberg CS. D-dimer antigen: current concepts and future prospects. Blood 2009; 113: 2878-2887.

[8] Robier C, Edler E, Klescher D, et al. False-positive D-dimer result in a latex-enhanced immunoassay caused by interfering human anti-mouse antibodies. Clin Chem Lab Med. 2014; 52: e253-e255.

[9] Kricka LJ. Human anti-animal antibody interferences in immunological assays. Clin Chem. 1999; 45: 942-956.

[10] Stegnar M, Božič M. Determination of D-dimer by different quantitative assays - a harmonization exercise. Biochem Medica 2008; 18: 216-223.

[11] Dempfle CE. D-dimer: standardization versus harmonization. Thromb Haemost. 2006; 95: 399-400.

[12] Mullier F, Vanpee D, Jamart J, et al. Comparison of five D-dimer reagents and application of an age-adjusted cut-off for the diagnosis of venous thromboembolism in emergency department. Blood Coagul Fibrinolysis 2014; 25: 309-315.

[13] Hager K, Platt D. Fibrin degradation product concentration (Ddimers) in the course of ageing. Gerontology 1995; 41: 159165 . 
[14] Douma RA, le Gal G, Söhne M, et al. Potential of an age adjusted D-dimer cut-off value to improve the exclusion of pulmonary embolism in older patients: a retrospective analysis of three large cohorts. BMJ 2010; 340: cl475.

[15] Righini M, Van Es J, Den Exter PL, et al. Age-adjusted D-dimer cutoff levels to rule out pulmonary embolism: the ADJUST-PE study. JAMA 2014; 311: 1117-1124.

[16] Jaconelli T, Eragat M, Crane S. Can an age-adjusted D-dimer level be adopted in managing venous thromboembolism in the emergency department? A retrospective cohort study. Eur J Emerg Med. 2018; 25: 288-294

[17] Dutton J, Dachsel M, Crane R. Can the use of an age-adjusted D-dimer cut-off value help in our diagnosis of suspected pulmonary embolism? Clin Med (Lond). 2018; 18: 293-296.

[18] Parry BA, Chang AM, Schellong SM, et al. International, multicenter evaluation of a new D-dimer assay for the exclusion of venous thromboembolism using standard and age-adjusted cutoffs. Thromb Res. 2018; 166: 63-70.
[19] Ackerly I, Klim S, McFarlane J, et al. Diagnostic utility of an age specific cut-off for D-dimer for pulmonary embolism assessment when used with various pulmonary embolism risk scores. Intern Med J. 2018; 48: 465-468.

[20] Sheele JM, Tang A, Farhan O, et al. A retrospective evaluation of the age-adjusted $\mathrm{D}$-dimer versus the conventional $\mathrm{D}$-dimer for pulmonary embolism. Blood Coagul Fibrinolysis 2018; 29: 344349.

[21] Nybo M, Hvas AM. Age-adjusted D-dimer cut-off in the diagnostic strategy for deep vein thrombosis: a systematic review. Scand J Clin Lab Invest. 2017; 77: 568-573.

[22] Zweig MH, Campbell G. Receiver-operating characteristic (ROC) plots: a fundamental evaluation tool in clinical medicine. Clin Chem. 1993; 39: 561-577.

(Török-Nagy Beáta, Budapest, Nagyvárad tér 4., 1089 e-mail: mail.nagy.beata@gmail.com)

\section{PÁLYÁZAT ORVOSI ÁLLÁSRA}

Pályázatot hirdető szerv neve, címe:

Nagykőrösi Rehabilitációs Szakkórház és Rendelöintézet

2750 Nagykőrös, Fáskert u. 1.

\section{Munkahely és munkakör megnevezése:}

1 fö Szemész szakorvos

Feladata: Intézményünk járóbeteg szakellátásán a szemészeti szakrendelés orvosi feladatainak elláása.

\section{Pályázati feltételek:}

- Orvosi Diploma

- Szakirányú szakvizsgát igazoló okirat

- Magyar állampolgárság

- MOK tagság igazolása

\section{Beküldendő:}

- Szakmai és személyi önéletrajz

- 3 hónapnál nem régebbi erkölcsi bizonyítvány

- Diploma, bizonyítvány fénymásolata

- OONY-ba vételi igazolás

- Nyilatkozat arról, hogy a pályázati anyagba a pályázatot elbíráló bizottság tagjai betekinthetnek.

\section{Juttatások, egyéb információk:}

A betölthető állással kapcsolatban részletes információ kérhető Tankó Ágota föigazgatótól (53/351-761).

A pályázat benyúitásának határideje: 2019. május 15.

Az állás betöltése az elbírálás után azonnal.

Pályázat benyújtása: postai úton és/vagy elektronikusan Nagykőrösi Rehabilitációs Szakkórház és Rendelöintézet 2750 Nagykörös, Fáskert u. 1. - Tankó Ágota föigazgató e-mail cím: tanko.agota@externet.hu

A cikk a Creative Commons Attribution 4.0 International License (https://creativecommons.org/licenses/by/4.0/) feltételei szerint publikált Open Access közlemény, melynek szellemében a cikk bármilyen médiumban szabadon felhasználható, megosztható és újraközölhetö, feltéve, hogy az eredeti szerző és a közlés helye, illetve a CC License linkje és az esetlegesen végrehajtott módositások feltüntetésre kerülnek. (SID_1) 